\title{
Histone-Lysine N-Methyltransferase SETD2
}

National Cancer Institute

\section{Source}

National Cancer Institute. Histone-Lysine N-Methyltransferase SETD2. NCI Thesaurus. Code C73696.

Histone-lysine methyltransferase SET D2 (2564 aa, $288 \mathrm{kDa}$ ) is encoded by the human SET D2 gene. This soluble, nuclear protein may play a role in epig enetic chromatin modification, and activation of transcription by RNA polymerase II. 